\title{
Screening of freshwater fish species for their susceptibility to a betanodavirus
}

\author{
Ryo Furusawa, Yasushi Okinaka*, Kazumasa Uematsu, Toshihiro Nakai
}

Graduate School of Biosphere Science, Hiroshima University, Higashi-Hiroshima 739-8528, Japan

\begin{abstract}
Betanodaviruses, the causative agents of viral nervous necrosis in marine fish, have bipartite positive-sense RNA genomes. Because the genomes are the smallest and simplest among viruses, betanodaviruses have been well studied using a reversed genetics system as model viruses. However, studies of virus-host interactions have progressed slowly because permissive hosts for betanodaviruses (basically larvae and juveniles of marine fish) are only available for limited periods of the year and are not suitable for the construction of a genetic engineering system. To obtain a model fish species that are not subject to these problems, 21 freshwater fish species were injected intramuscularly with a betanodavirus (redspotted grouper nervous necrosis virus) and tested for their susceptibility to the virus. Based on their responses, the tested fish were classified into 3 groups: 4 susceptible fish, 10 less susceptible fish, and 7 resistant fish. The susceptible fish, celebes rainbowfish Telmatherina ladigesi, threadfin rainbowfish Iriatherina werneri, dwarf rainbowfish Melanotaenia praecox, and medaka Oryzias latipes, exhibited erratic swimming and eventually died within $10 \mathrm{~d}$ post-inoculation. The virus was specifically localized in the brains, spinal cords, and retinas of the infected fish, similar to the pattern of infection in naturally infected marine fish. We believe that these susceptible freshwater fish species could act as good host models for betanodavirus-fish interaction studies.
\end{abstract}

KEY WORDS: Betanodavirus - Freshwater fish - Model fish - Experimental infection - Medaka · Rainbowfish

Resale or republication not permitted without written consent of the publisher

\section{INTRODUCTION}

Betanodaviruses, members of the family Nodaviridae, are the causative agents of a highly destructive disease of hatchery-reared larvae and juveniles of a variety of marine fish. In some species, adult and mature fish have also been reported to suffer from the disease. The disease, designated viral nervous necrosis (VNN) when it was first described in 1990 (Yoshikoshi \& Inoue 1990), is also known as viral encephalopathy and retinopathy (Office International des Epizooties 2003). VNN disease has spread to $>30$ marine fish species from 14 families in the Indo-Pacific and Mediterranean regions, Scandinavia, and North America. The virus localizes in the brain, spinal cord, and retina of the affected fish. Affected fish exhibit erratic swimming patterns and a range of neurological abnormalities, including vacuolization and cellular necrosis in the central nervous system and retina (Munday et al. 2002).

Betanodaviruses are nonenveloped, spherical viruses with a bipartite positive-sense RNA genome RNA1 (3.1 kb) and RNA2 (1.4 kb), which encode an RNA-dependent RNA polymerase (protein A) and the coat protein $(\mathrm{CP})$, respectively (Schneemann et al. 2005). Recently, we characterized a subgenomic RNA3 $(0.4 \mathrm{~kb})$ which encodes protein B2, a suppressor for post-transcriptional gene silencing (Iwamoto et al. 2005). The viruses can be classified into 4 types, designated striped jack nervous necrosis virus (SJNNV), barfin flounder nervous necrosis virus (BFNNV), tiger puffer nervous necrosis virus (TPNNV), and redspotted grouper nervous necrosis virus (RGNNV), based on similarities in the partial RNA2 sequences (Nishizawa et al. 1997). The host ranges of SJNNV and TPNNV are limited to striped jack Pseudocaranx den- 
tex and tiger puffer Takifugu rubripes, respectively, whereas BFNNV has been isolated from some coldwater species, such as barfin flounder Verasper moseri, Pacific cod Gadus macrocephalus, and Atlantic halibut Hippoglossus hippoglossus. RGNNV has a broad host range and causes disease among a variety of warm water fish species, particularly groupers and sea bass (Munday et al. 2002).

Betanodaviruses have key features as model viruses, as is also the case with the insect alphanodaviruses (Ball \& Johnson 1998), the other genus of the family Nodaviridae. Betanodaviruses have one of the smallest genomes (4.5 kb in total) among the known viruses, which encode only 3 viral proteins (protein $\mathrm{A}, \mathrm{CP}$, and protein B2). Furthermore, a genetic engineering system has already been established based on a cDNAmediated infectious RNA transcription strategy (Iwamoto et al. 2001, 2004). Qualitative and quantitative analysis of virus multiplication is possible with betanodaviruses, using cultured cells (Frerichs et al. 1996, Chi et al. 1999, Iwamoto et al. 1999, 2000). However, studies of virus-host interactions have progressed slowly because of the limited availability of host fish. Betanodaviruses basically infect marine fish larvae and juveniles, which are only available for a few months of the year. Other experimental problems with marine fish species are their long life cycles, large bodies, and the difficult rearing conditions required, which preclude easy experimentation, and especially the use of genetic engineering strategies. In the present study, to overcome these problems, we have tested several small ornamental freshwater fish as model hosts for their susceptibility to RGNNV, which has the broadest host ranges among the 4 types of viruses (Nishizawa et al. 1997).

\section{MATERIALS AND METHODS}

Virus and cells. RGNNV (SGWak97 strain, Iwamoto et al. 1999) was used in this study. The E-11 cell line (Iwamoto et al. 2000) was grown at $25^{\circ} \mathrm{C}$ in Leibovitz's L-15 medium (Invitrogen) supplemented with 5\% fetal bovine serum.

Preparation of RGNNV virions. The virus was inoculated into E-11 cells, and the cells were incubated at $25^{\circ} \mathrm{C}$ for 3 to $5 \mathrm{~d}$. The culture supernatants of the infected cells were harvested and mixed with $3 \mathrm{vol}$ of $40 \%$ (w/v) polyethylene glycol (PEG 8000; Nacalai Tesque). The mixtures were incubated on ice for $1 \mathrm{~h}$ and centrifuged at $12000 \times g$ for $15 \mathrm{~min}$ at $4^{\circ} \mathrm{C}$ to sediment the progeny viruses. The sedimented viruses were suspended in extraction buffer $(0.1 \mathrm{M}$ Tris- $\mathrm{HCl}$, $1 \mathrm{mM}$ EDTA, $\mathrm{pH} 7.2$ ) and stored at $-80^{\circ} \mathrm{C}$ until use. Viral titers were quantified by determining the $50 \%$ tissue culture infective dose $\left(\mathrm{TCID}_{50}\right) \mathrm{ml}^{-1}$ as described in Reed \& Muench (1938).

Intramuscular injection of freshwater fish. Twentyone freshwater fish species were purchased from local ornamental fish markets (Table 1). Fish were maintained at $25^{\circ} \mathrm{C}$ throughout the experimental period, and fed daily with powdered dry flakes (TetraMin, TetraWelke). For intramuscular inoculation, the fish were injected with $5 \mu \mathrm{l}$ of RGNNV $\left(10^{7.0} \mathrm{TCID}_{50} \mathrm{ml}^{-1}\right)$ suspensions using a microsyringe (Hamilton). As a positive control, sevenband grouper Epinephelus septemfasciatus, which is one of the most susceptible fish to RGNNV (Tanaka et al. 1998), were similarly injected with the virus. Inoculated fish were monitored daily for $10 \mathrm{~d}$ for the appearances of erratic swimming (morbidity) and death (mortality).

Titration of viruses in fish brains. Brains were recovered from the dead or moribund fish. If fish were apparently healthy throughout the experimental periods, their brains were collected at $10 \mathrm{~d}$ post-inoculation. The brain samples were thoroughly homogenized with $500 \mu \mathrm{l}$ of Hanks' balanced salt solution (Nissui), and the homogenates were passed through a $0.45 \mu \mathrm{m}$ membrane filter (Advantec). Viral titers of the homogenates were quantified as described above.

Histopathology. Fish were immersed in Bouin's solution for $1 \mathrm{wk}$ at $4^{\circ} \mathrm{C}$ and then soaked in $15 \%$ trichloroacetic acid for $1 \mathrm{wk}$ at $4{ }^{\circ} \mathrm{C}$ for decalcification. The fish samples were then embedded in paraffin and sectioned sagittaly to $8 \mu \mathrm{m}$. One of 2 consecutive sections was stained with hematoxylin and eosin (H\&E), and the other was subjected to immunofluorescence staining with anti-SJNNV rabbit polyclonal antibody and fluorescein isothiocyanate-conjugated swine immunoglobulin raised against rabbit immunoglobulin (Dako), as described previously (Nguyen et al. 1996). This anti-SJNNV polyclonal antibody has been shown to detect RGNNV (Iwamoto et al. 2004).

\section{RESULTS}

\section{Susceptibility of freshwater fish to RGNNV}

The 21 freshwater fish species (Table 1) were intramuscularly injected with RGNNV and monitored for the appearance of erratic swimming as the clinical sign of VNN. Among the species tested, celebes rainbowfish, dwarf rainbowfish, threadfin rainbowfish, and medaka exhibited erratic swimming within $10 \mathrm{~d}$ after inoculation (Table 1). Cumulative morbidity in celebes rainbowfish, dwarf rainbowfish, threadfin rainbowfish, and medaka was 90, 86, 40, and $76 \%$, respectively. All the fish exhibiting erratic swimming after virus inocu- 
Table 1. Characteristics of several freshwater fish species with respect to susceptibility to redspotted grouper nervous necrosis virus (RGNNV). Size: averaged body length. ES/Total: number of fish showing erratic swimming (ES)/total number of fish examined. Vacuolation: Samples were sectioned and used for H\&E staining. All (+), $1(+/-)$ or none (-) of the samples tested showed vacuolation in the central nervous systems and retinas. ND: not examined. FAT (immunofluorescence staining): Samples were sectioned and used for FAT. In celebes rainbowfish, threadfin rainbowfish, dwarf rainbowfish, and medaka, only fish exhibiting ES were used. Observed fluorescent signals covered approximately 80 to $90 \%(+++), 50$ to $79 \%(++), 1$ to $49 \%$ (+), or $0 \%(-)$ of the brain areas of the samples on average. Virus isolation: brain samples were collected from fish exhibiting ES. Numbers in parentheses are data obtained from fish not showing ES during experimental periods. Virus+/Total: number of fish from which the virus was isolated using cultured cells/total number of fish examined. Viral titer: data are means. -: viral titers below detection limits, which varied depending on experiment as well as fish species. TCID $50: 50 \%$ tissue culture infective dose

\begin{tabular}{|c|c|c|c|c|c|c|}
\hline \multirow[t]{2}{*}{ Species } & \multirow{2}{*}{$\begin{array}{l}\text { Size } \\
(\mathrm{cm})\end{array}$} & \multirow[t]{2}{*}{ ES/Total } & \multirow[t]{2}{*}{ Vacuolation } & \multirow[t]{2}{*}{ FAT } & \multicolumn{2}{|c|}{ Virus isolation } \\
\hline & & & & & Virus $^{+} /$Total & Viral titer $\left(\right.$TCID $\left._{50} \mathrm{~g}^{-1}\right)$ \\
\hline $\begin{array}{l}\text { Celebes rainbowfish } \\
\text { Telmatherina ladigesi }\end{array}$ & 2.7 & $9 / 10$ & - & +++ & $6 / 6$ & 10.2 \\
\hline $\begin{array}{l}\text { Dwarf rainbowfish } \\
\text { Melanotaenia praecox }\end{array}$ & 2.8 & $4 / 10$ & - & ++ & $2 / 2(3 / 5)$ & $8.8(7.7)$ \\
\hline $\begin{array}{l}\text { Threadfin rainbowfish } \\
\text { Iriatherina werneri }\end{array}$ & 2.3 & $6 / 7$ & $+/-$ & +++ & $4 / 4(1 / 1)$ & $10.1(9.7)$ \\
\hline $\begin{array}{l}\text { Medaka } \\
\text { Oryzias latipes }\end{array}$ & 1.9 & $13 / 17$ & - & +++ & $9 / 9(4 / 5)$ & $9.4(9.4)$ \\
\hline $\begin{array}{l}\text { Guppy } \\
\text { Poecilia reticulata }\end{array}$ & 2.7 & $0 / 11$ & - & + & $(4 / 5)$ & $(7.6)$ \\
\hline $\begin{array}{l}\text { Angelfish } \\
\text { Pterophyllum scalare }\end{array}$ & 1.7 & $0 / 10$ & ND & ND & $(5 / 5)$ & $(6.8)$ \\
\hline $\begin{array}{l}\text { Blue streak hap } \\
\text { Labidochromis caeruleus }\end{array}$ & 2.7 & $0 / 10$ & - & + & $(5 / 5)$ & $(7.5)$ \\
\hline $\begin{array}{l}\text { Climbing perch } \\
\text { Anabas testudineus }\end{array}$ & 4.9 & $0 / 4$ & - & + & $(1 / 2)$ & (6.1) \\
\hline $\begin{array}{l}\text { Golden mbuna } \\
\text { Melanochromis auratus }\end{array}$ & 2.1 & $0 / 6$ & - & + & $(1 / 2)$ & (6.6) \\
\hline $\begin{array}{l}\text { Honey gourami } \\
\text { Trichogaster chuna }\end{array}$ & 3.0 & $0 / 9$ & ND & ND & $(5 / 5)$ & $(7.4)$ \\
\hline $\begin{array}{l}\text { Kenyi cichlid } \\
\text { Pseudotropheus lombardoi }\end{array}$ & 2.1 & $0 / 3$ & ND & ND & $(2 / 2)$ & (7.9) \\
\hline $\begin{array}{l}\text { Pygmy gourami } \\
\text { Trichopsis pumila }\end{array}$ & 2.0 & $0 / 6$ & ND & ND & $(4 / 6)$ & (8.6) \\
\hline $\begin{array}{l}\text { Siamese fighting fish } \\
\text { Betta splendens }\end{array}$ & 2.5 & $0 / 10$ & - & + & $(4 / 5)$ & $(7.5)$ \\
\hline $\begin{array}{l}\text { Three-spot gourami } \\
\text { Trichogaster trichopterus }\end{array}$ & 4.2 & $0 / 9$ & ND & ND & $(3 / 5)$ & $(7.7)$ \\
\hline $\begin{array}{l}\text { Dwarf gourami } \\
\text { Colisa lalia }\end{array}$ & 3.1 & $0 / 5$ & ND & ND & $(0 / 2)$ & - \\
\hline $\begin{array}{l}\text { Goldfinned barb } \\
\text { Puntius sachsii }\end{array}$ & 1.9 & $0 / 10$ & - & - & $(0 / 5)$ & - \\
\hline $\begin{array}{l}\text { Goldfish } \\
\text { Carassius auratus }\end{array}$ & 2.6 & $0 / 10$ & - & - & $(0 / 5)$ & - \\
\hline $\begin{array}{l}\text { Zebrafish } \\
\text { Danio rerio }\end{array}$ & 2.6 & $0 / 10$ & - & - & $(0 / 4)$ & - \\
\hline $\begin{array}{l}\text { Bronze corydoras } \\
\text { Corydoras aeneus }\end{array}$ & 2.7 & $0 / 10$ & - & - & $(0 / 5)$ & - \\
\hline $\begin{array}{l}\text { Sailfin catfish } \\
\text { Liposarcus multiradiatus }\end{array}$ & 4.4 & $0 / 10$ & - & - & $(0 / 5)$ & - \\
\hline $\begin{array}{l}\text { Neon tetra } \\
\text { Paracheirodon innesi }\end{array}$ & 2.1 & $0 / 10$ & - & - & $(0 / 5)$ & - \\
\hline $\begin{array}{l}\text { Sevenband grouper } \\
\text { Epinephelus septemfasciatus }\end{array}$ & 5.3 & $12 / 12$ & + & +++ & $(5 / 5)$ & (9.1) \\
\hline
\end{tabular}




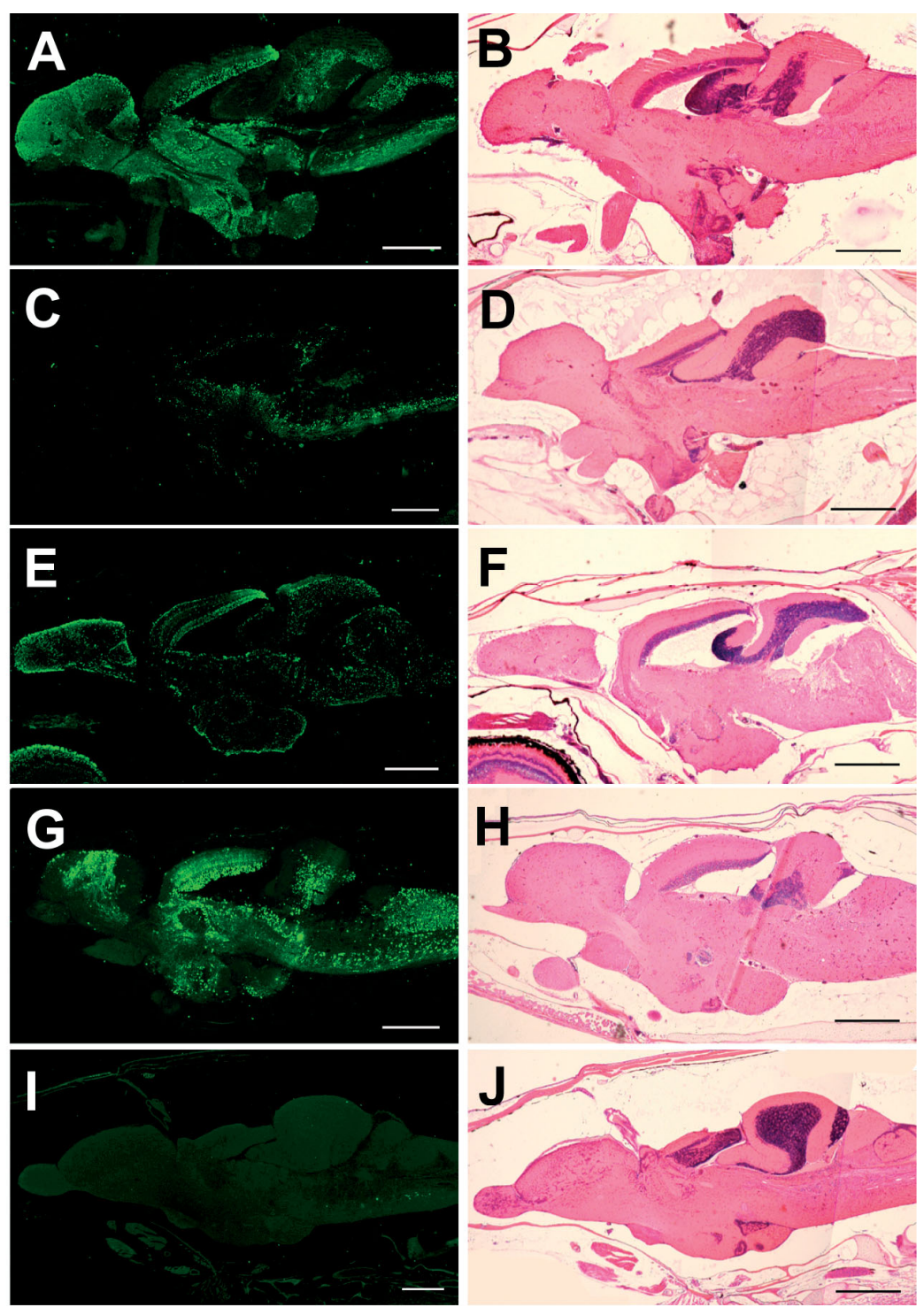

Fig. 1. Immunofluorescence staining and histopathology of the freshwater fish brains inoculated with redspotted grouper nervous necrosis virus (RGNNV). $(\mathrm{A}, \mathrm{B})$ Celebes rainbowfish, $(\mathrm{C}, \mathrm{D})$ dwarf rainbowfish, $(\mathrm{E}, \mathrm{F})$ threadfin rainbowfish, and $(\mathrm{G}, \mathrm{H})$ medaka were injected intramuscularly with RGNNV and sacrificed after showing erratic swimming. In the case of $(\mathrm{I}, \mathrm{J})$ zebrafish, normally swimming fish were collected $10 \mathrm{~d}$ after virus inoculation. The fish were sectioned through the median lines of the brains and subjected to immunofluorescence staining with $(\mathrm{A}, \mathrm{C}, \mathrm{E}, \mathrm{G}, \mathrm{I})$ anti-striped jack nervous necrosis virus (STNNV) antibody or $(\mathrm{B}, \mathrm{D}, \mathrm{F}, \mathrm{H}, \mathrm{J}) \mathrm{H} \& \mathrm{E}$ staining. Scale bars $=1 \mu \mathrm{m}$. Representative data for each species are shown

lations eventually died within 3 to 5 d (data not shown). No apparent clinical sign or mortality was observed in the other 17 species, though blue streak hap showed slow movements for a few days, but finally recovered from erratic swimming during the experimental period. All of the sevenband groupers inoculated with RGNNV showed apparent clinical signs, and some of these fish died within $10 \mathrm{~d}$.
To know whether the virus multiplied in these erratically swimming fish and did not propagate in the others, inoculated fish were examined by immunofluorescence staining (FAT). In the 4 susceptible species (celebes rainbowfish, dwarf rainbowfish, threadfin rainbowfish, and medaka), strong fluorescence signals, indicative of the presence of the virus, were obtained in the brains, spinal cords, and retinas (Table 1, Fig. 1). Although similar neurotropism of the virus was observed in golden mbuna, Siamese fighting fish, climbing perch, blue streak hap, and guppy, the signal intensity was much lower than that in the 4 susceptible species. No evidence of virus multiplication was obtained in bronze corydoras, goldfinned barb, goldfish, sailfin catfish, neon tetra, or zebrafish (Table 1). Histopathologically, the affected sevenband grouper showed the typical vacuolation in the central nervous tissues and retinas. However, such vacuolation was not observed in any fish species tested except 1 positive threadfin rainbowfish sample (Table 1, Fig. 1). Angelfish, honey gourami, kenyi cichlid, pygmy gourami, three-spot gourami, and dwarf gourami were not tested histopathologically.

\section{Virus multiplication in the brains}

Virus multiplication was evaluated by the viral titers in the brains of freshwater fish injected intramuscularly with RGNNV (Table 1). Viral titers ranged from $10^{8.8}$ to $10^{10.2} \mathrm{TCID}_{50} \mathrm{~g}^{-1}$ brain tissue in the dead or moribund fish of the 4 susceptible species: celebes rainbowfish, dwarf rainbowfish, threadfin rainbowfish, and medaka (Table 1). The titers in celebes rainbowfish, threadfin rainbowfish, and medaka exceeded that in sevenband grouper, the originated host for RGNNV. Similar or slightly low viral titers were obtained in the surviving fish of these 4 susceptible species (Table 1). The species that showed no clinical signs during the experimental period (angelfish, golden mbuna, siamese fighting fish, climbing perch, blue streak hap, guppy, honey gourami, kenyi cichlid, three-spot gourami, and pygmy gourami) gave titers from $10^{6.1}$ to $10^{8.6} \mathrm{TCID}_{50} \mathrm{~g}^{-1}$ brain tissue. In contrast, 
viral titers were below the detection limits in bronze corydoras, dwarf gourami, goldfinned barb, goldfish, sailfin catfish, neon tetra, and zebrafish (Table 1).

\section{DISCUSSION}

In the present study we tested 21 ornamental freshwater fish for susceptibility to RGNNV and demonstrated that 4 of these, i.e. inoculated celebes rainbowfish, dwarf rainbowfish, threadfin rainbowfish, and medaka, showed erratic swimming followed by death as was originally observed in marine fish species. In these freshwater fish, the virus was localized in the brains, spinal cords, and retinas. Another 10 species tested in our study had low levels of virus multiplication in the neural tissues without showing clinical signs of infection. Although betanodavirus infection has recently been reported in cultured freshwater fish, including guppy and sturgeon Acipenser gueldestaedi, the infected fish in these studies survived for a long time despite the fact that they exhibited clinical signs (Hegde et al. 2003, Athanassopoulou et al. 2004). Furthermore, in the former study, the healthy guppy inoculated experimentally with the RGNNV type virus, isolated from diseased guppy, did not show any clinical signs (Hegde et al. 2003). These data support our observation that guppy was less susceptible to RGNNV.

According to the phylogenetic tree of the freshwater fish used in this study, the fish are classified into 3 series: Otophysi, Smegmamorpha, and Perciforpha (Fig. 2). Interestingly, the Smegmamorpha series is comprised of all the susceptible fish and 1 less suscep- tible species (guppy). The Perciforpha includes all the less susceptible fish, except guppy and 1 resistant species (dwarf gourami). Finally, the Otophysi is comprised exclusively of the resistant species. These data indicate that, basically, freshwater fish species in the same series have similar susceptibilities to betanodaviruses since most of the tested species which belonged to the Smegmamorpha were susceptible. Thus, there seem to be other susceptible freshwater fish species in the Smegmamorpha. This information should be useful to prevent or control future VNN outbreaks in freshwater fish. The marine fish, recognized as permissive hosts for betanodaviruses, belong mainly to the Perciforpha (Munday et al. 2002), in which no susceptible freshwater species were found in this study. This discrepancy in betanodavirus susceptibility observed between freshwater fish and marine fish remains to be addressed. However, one possible explanation is that the freshwater fish with a low level of susceptibility to RGNNV at their adult stages are susceptible to it at their larval or juvenile stages similar to marine fish hosts. Viral inoculations of larvae or juveniles in these less susceptible species as well as the susceptible species using an immersion method may give insight into the discrepancy.

Generally, histopathological features, characterized by vacuolation of the central nervous system and retina, have been observed in VNN-affected marine fish (Munday et al. 2002). However, in virus-infected freshwater fish, no obvious lesions were observed in the central nervous system or retina, except in 1 threadfin rainbowfish sample, even though high levels of viral accumulation were observed in these tissues (Table 1, Fig. 1). Therefore, we conclude that the

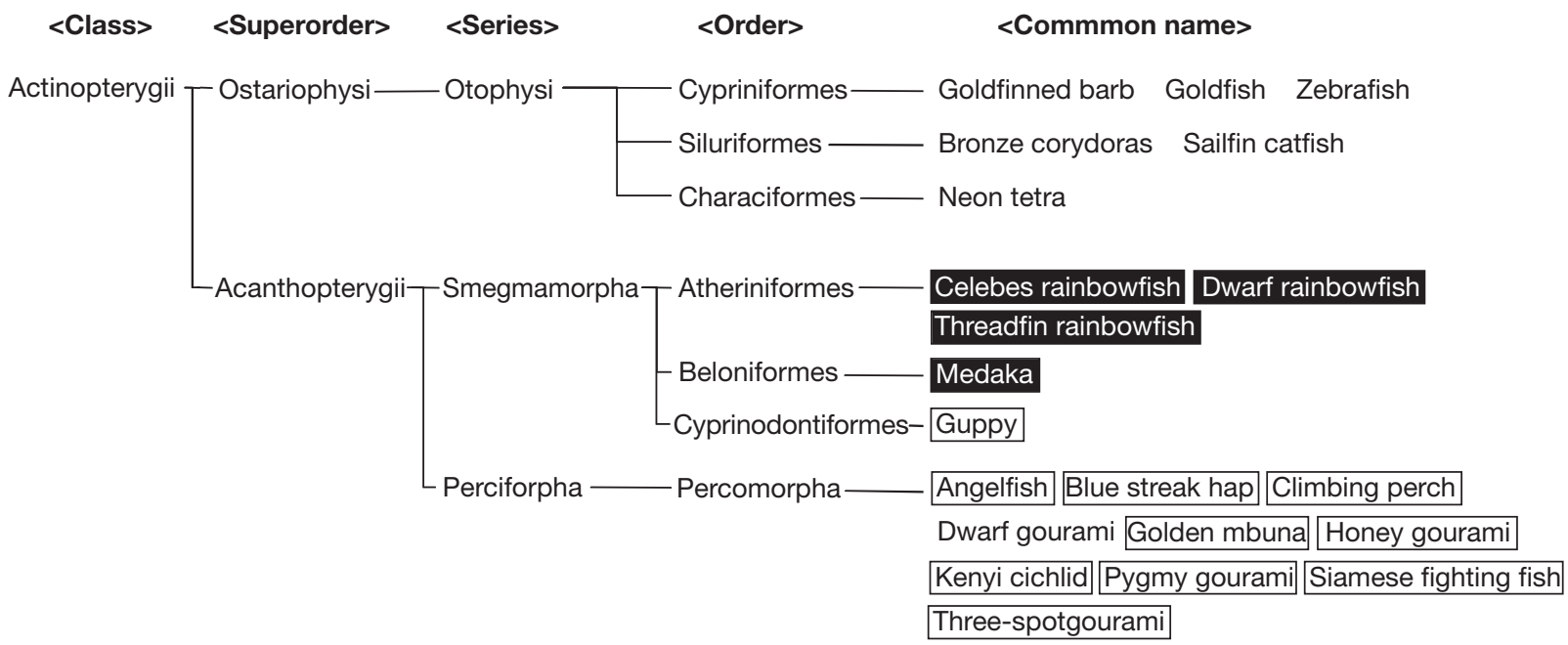

Fig. 2. Taxonomical relationships among the freshwater fish used in the present study. Susceptible and less susceptible fish against redspotted grouper nervous necrosis virus (RGNNV) are indicated by black boxes and white boxes, respectively 
occurrence of erratic swimming in freshwater fish does not necessarily require obvious lesion formation such as vacuolation. Instead, some invisible histopathological abnormalities may have occurred in the target tissues of infected freshwater fish. Namely, the histopathology in the virus-infected freshwater fish may differ from that observed in affected marine fish. Alternatively, infected freshwater fish may die before showing vacuolation in the target tissues. VNNaffected larval striped jack Pseudocaranx dentex seldom showed vacuolation in the central nervous system or retina, although those tissues accumulated significant levels of virus (authors' unpubl. data).

In dwarf rainbowfish, threadfin rainbowfish, and medaka, the levels of virus multiplication in the brain were similar in the normal and erratically swimming fish (Table 1). These results suggest that the appearance of erratic swimming is not controlled simply by the amount of virus in the brain, even though viral accumulation is a prerequisite for development of clinical signs. This apparent discrepancy may arise from the nonuniform viral accumulation in the brain. This hypothesis is supported by the fact that the patterns of viral antigens localized within the brain varied among the infected fish.

In the present study, celebes rainbowfish, dwarf rainbowfish, threadfin rainbowfish, and medaka were susceptible to RGNNV. Celebes rainbowfish, threadfin rainbowfish, and medaka, in particular, showed considerable morbidity rates and viral titers in the brains of affected fish. Therefore, these 3 species would appear to be good model fish candidates for betanodavirus infection experiments. Medaka has been used as a vertebrate model for various studies involving embryology, neuroembryology, pharmacology, toxicology, genomics, etc. (Ishikawa 2000, Wittbrodt et al. 2002). Furthermore, fundamental experimental techniques, reversed genetics, classical genetics, and breeding systems are already available for medaka. Such information and techniques would greatly facilitate the study of host factors for betanodaviruses. Rainbowfish are popular ornamental fish and were originally found in Australia, New Guinea, and Indonesia. They are easy to rear in small aquariums and have been used in ecotoxicology studies (Humphrey \& Klumpp 2003, Harford et al. 2006). Although rainbowfish have not yet been recognized as vertebrate models, these fish seem to be good experimental hosts for betanodavirus studies because of their strong susceptibility to RGNNV (Table 1). It remains to be seen whether rainbowfish are suitable for the construction of genetic engineering systems. Collectively, medaka and rainbowfish, which are not subject to many of the problems in marine fish hosts, appear suitable for extensive studies of betanodavirus-fish interactions.
We will further investigate the susceptibility of these fish species to the other 3 types of betanodaviruses, SJNNV, TPNNV, and BFNNV, to evaluate the suitability of these fish for host-specificity studies.

Acknowledgements. We are grateful to the members of Kamiura Station of National Research Institute of Aquaculture, Fisheries Research Agency for supplying sevenband grouper. This work was supported in part by grants-in-aid for scientific research $(16380132,16580151,18580185)$ from the Ministry of Education, Culture, Sports, Science and Technology, Japan, and a grant-in-aid for scientific research (18076) from the Ministry of Agriculture, Forestry and Fisheries of Japan.

\section{LITERATURE CITED}

Athanassopoulou F, Billinis C, Prapas T (2004) Important disease conditions of newly cultured species in intensive freshwater farms in Greece: first incidence of nodavirus infection in Acipenser sp. Dis Aquat Org 8:247-252

Ball LA, Johnson KL (1998) Nodaviruses of insects. In: Miller LK, Ball LA (eds) The insect viruses. Plenum Press, New York, p 225-267

Chi SC, Hu WW, Lo BJ (1999) Establishment and characterization of a continuous cell line (GF-1) derived from grouper, Epinephelus coioides (Hamilton): a cell line susceptible to grouper nervous necrosis virus (GNNV). J Fish Dis 22:173-182

Frerichs GN, Rodger HD, Peric Z (1996) Cell culture isolation of piscine neuropathy nodavirus from juvenile sea bass, Dicentrarchus labrax. J Gen Virol 77:2067-2071

Harford AJ, O'Halloran K, Wright PF (2006) Flow cytometric analysis and optimisation for measuring phagocytosis in three Australian freshwater fish. Fish Shellfish Immunol 20:562-573

Hegde A, Teh HC, Lam TJ, Sin YM (2003) Nodavirus infection in freshwater ornamental fish, guppy, Poicelia reticulata-comparative characterization and pathogenicity studies. Arch Virol 148:575-586

Humphrey C, Klumpp DW (2003) Toxicity of chlorpyrifos to the early life history stages of eastern rainbowfish Melanotaenia splendida splendida (Peters, 1866) in tropical Australia. Environ Toxicol 18:418-427

Ishikawa Y (2000) Medakafish as a model system for vertebrate developmental genetics. Bioessays 22:487-495

Iwamoto T, Mori K, Arimoto M, Nakai T (1999) High permissivity of the fish cell line SSN-1 for piscine nodaviruses. Dis Aquat Org 39:37-47

Iwamoto T, Nakai T, Mori K, Arimoto M, Furusawa I (2000) Cloning of the fish cell line SSN-1 for piscine nodaviruses. Dis Aquat Org 43:81-89

Iwamoto T, Mise K, Mori K, Arimoto M, Nakai T, Okuno T (2001) Establishment of an infectious RNA transcription system for striped jack nervous necrosis virus, the type species of the betanodaviruses. J Gen Virol 82: 2653-2662

Iwamoto T, Okinaka Y, Mise K, Mori K, Arimoto M, Okuno T, Nakai T (2004) Identification of host-specificity determinants in betanodaviruses using reassortants between striped jack nervous necrosis virus and sevenband grouper nervous necrosis virus. J Virol 78:1256-1262

Iwamoto T, Mise K, Takeda A, Okinaka Y, Mori K, Arimoto M, Okuno T, Nakai T (2005) Characterization of striped jack nervous necrosis virus subgenomic RNA3 and biological ac- 
tivities of its encoded protein B2. J Gen Virol 86:2807-2816 Munday BL, Kwang J, Moody N (2002) Betanodavirus infections of teleost fish: a review. J Fish Dis 25:127-142

Nishizawa T, Furuhashi M, Nagai T, Nakai T, Muroga K (1997) Genomic classification of fish nodaviruses by molecular phylogenetic analysis of the coat protein gene. Appl Environ Microbiol 63:1633-1636

Office International des Epizooties (2003) Viral encephalopathy and retinopathy. In: Manual of diagnostic tests for aquatic animals. Office International des Epizooties, Paris, p 135-141

Pradel E, Ewbank JJ (2004) Genetic models in pathogenesis. Annu Rev Genet 38:347-363

Reed LJ, Muench H (1938) A simple method of estimating

Editorial responsibility: Mark Crane,

Geelong, Victoria, Australia fifty percent end points. Am J Hyg 27:493-497

Schneemann A, Ball LA, Delsert C, Johnson JE, Nishizawa T (2005) Family Nodaviridae. In: Fauquet CM, Mayo MA, Maniloff J, Desselberger U, Ball LA (eds) Virus taxonomy. Academic Press, San Diego, p 865-872

Tanaka S, Aoki H, Nakai T (1998) Pathogenicity of the nodavirus detected from diseased sevenband grouper Epinephelus septemfasciatus. Fish Pathol 33:31-36

Wittbrodt J, Shima A, Schartl M (2002) Medaka - a model organism from the far east. Nature Rev Genet 3:53-64

Yoshikoshi K, Inoue K (1990) Viral nervous necrosis in hatchery-reared larvae and juveniles of Japanese parrotfish, Oplegnathus fasciatus (Temminck \& Schlegel). J Fish Dis 13:69-77

Submitted: May 8, 2007; Accepted: June 26, 2007

Proofs received from author(s): August 24, 2007 